\title{
Effect of Spacing and Nutrient Levels on Growth Attributes and Yield of Finger Millet (Eleusine coracana L. Gaertn) Cultivated under Guni Planting Method in Red Sandy Loamy Soil of Karnataka, India
}

\author{
G. Prakasha ${ }^{1 *}$, K.N. Kalyana Murthy ${ }^{1}$, A.S. Prathima ${ }^{2}$ and Rohani N. Meti ${ }^{1}$ \\ ${ }^{1}$ Department of Agronomy, UAS, GKVK, Bengaluru, Karnataka, India \\ ${ }^{2}$ Department of Agronomy, UAS, Raichur, Karnataka, India \\ *Corresponding author
}

\begin{abstract}
A B S T R A C T
Field experiment was conducted at Zonal Agricultural Research Station, University of Agricultural Sciences, Bengaluru, during kharif 2014 on red sandy loam soil to investigate

Keywords

Finger millet

(Eleusine coracana L. Gaertn)

Article Info

Accepted:

12 April 2018

Available Online:

10 May 2018

the effect of spacing and nutrient levels on growth and yield of finger millet. Experiment was conducted by using randomised complete block design with 3 replications and 8 treatments comprising of two spacings ( $45 \times 45 \mathrm{~cm}$ and $60 \mathrm{X} 60 \mathrm{~cm})$ with three levels of NPK (50, 75 and $100 \%$ RDF) compared with farmer's method of guni planting (60 X 60 $\mathrm{cm}$ with only FYM) and UAS package of practice. Study revealed that at 30, 60 and 90 DAS, significantly higher plant height $(31.20 \mathrm{~cm}, 78.29 \mathrm{~cm}, 90.80 \mathrm{~cm}$, respectively), leaf area $\left(1137 \mathrm{~cm}^{2}\right.$ plant ${ }^{-1}, 7184 \mathrm{~cm}^{2}$ plant $^{-1}$ and $26322 \mathrm{~cm}^{2}$ plant ${ }^{-1}$, respectively), total dry matter (2.06 g plant $^{-1}, 10.58$ g plant $^{-1}$ and 20.62 g plant $^{-1}$, respectively), RGR (0.422 $\mathrm{g} \mathrm{day}^{-1}$ $\mathrm{dm}^{2}$ and $0.284 \mathrm{~g} \mathrm{day}^{-1} \mathrm{dm}^{2}$ at 30-60 days and 60-90 days interval, respectively), CGR (7.230 $\mathrm{g} \mathrm{dm}^{-2}$ day $^{-1}$ and $5.841 \mathrm{~g} \mathrm{dm}^{-2}$ day $^{-1}$ at 30-60 days and 60-90 days interval, respectively), NAR (0.0637 $\mathrm{g} \mathrm{day}^{-1} \mathrm{dm}^{2}$ and $0.0539 \mathrm{~g} \mathrm{day}^{-1} \mathrm{dm}^{2}$ at 30-60 days and 60-90 days interval, respectively) and seed yield $\left(4166 \mathrm{~kg} \mathrm{ha}^{-1}\right)$ were recorded with spacing of 60 $\mathrm{x} 60 \mathrm{~cm}+100 \%$ RDF application.
\end{abstract}

\section{Introduction}

Finger millet (Eleusine coracana $\mathrm{L}$. Gaertn) is an important small millet crop grown in India and has the pride of place in having highest productivity among millets. It is also known as ragi, African millet and Bird's foot millet and an important staple food crop in part of eastern and central Africa and India. In India, it is cultivated in Karnataka, Tamil Nadu, Andhra Pradesh, Orissa, Jharkhand, Uttaranchal, Maharashtra, and Gujarat. The annual cultivated area under millets is around 29 million hectares, of which small millets alone accounts for about 3.5 million hectares. Among small millets, finger millet alone occupies 50 per cent area and contributes more than $2 / 3^{\text {rd }}$ production $(2.8$ million tonnes). The striking feature of finger millet is its ability to adjust to different agro-climatic conditions, easy cultivation, free from major pests and diseases and drought tolerance, effective in suppressing weed growth, and able to grow on marginal lands with poor soil 
fertility have made this crop an indispensable component of dry farming system. Though finger millet is valued by traditional farmers as a low fertilizer input crop, under these conditions, it suffers from low yields. Most of the soils in the semi-arid tropics, where finger millet is grown, are deficient in major and micronutrients, mainly due to continuous cropping, low use of mineral fertilizer, poor recycling of crop residues, and low rates of organic matter application which can limit yield potential. Therefore, it is important to optimize nutrient management practices and other related factors affecting finger millet cultivation in order to attain better yields under the comparatively marginal local growing conditions.

The productivity of finger millet can be increased by applying judicious combination of organic and inorganic fertilizers along with the scientific validation of indigenous technical knowledge of the farmers, which helps to improve the soil health as well as the productivity of finger millet (Ramamurthy et al., 1993). Guni method has been a best example for farmer's wide knowledge in cultivation methods. In guni method, land preparation is as usual for crop production and then they create a grid similar to that with SRI method of paddy cultivation. At intersection points a small pit (guni) or scoop is formed at a spacing of $2 \times 2$ feet and approximately 0.75 $\mathrm{kg}$ of FYM and recommended dose of inorganic fertilizers applied to the guni and mixed with a top soil. Then young seedlings of 20 days old are planted two in each guni. The presence of organic manure along with inorganic fertilizers helps in better availability of nutrients and moisture. Besides these, other advantages are reduction in seed rate, easy inter cultivation, better weed management and drip irrigation can also be adopted by providing wider spacing $(60 \times 60 \mathrm{~cm})$ than the conventional method of planting $(30 \times 10 \mathrm{~cm})$. Hence the present investigation was taken to develop a suitable nutrient management packages under guni (pit) method of finger millet.

\section{Materials and Methods}

A field experiment was carried out to study the "Effect of spacing and nutrient levels on growth attributes and yield of finger millet (Eleusine coracana L. Gaertn) cultivated under guni planting method in red sandy loamy soil of Karnataka." during Kharif 2014 at Zonal Agricultural Research Station, University of Agricultural Sciences, Bengaluru. The field trial was laid out in a randomized complete block design with three replications and 8 treatments combinations viz., $\mathrm{T}_{1}$ : Spacing of $45 \times 45 \mathrm{~cm}+50 \% \mathrm{RDF}$, $\mathrm{T}_{2}$ : Spacing of $45 \times 45 \mathrm{~cm}+75 \% \mathrm{RDF}, \mathrm{T}_{3}$ : Spacing of $45 \times 45 \mathrm{~cm}+100 \% \mathrm{RDF}, \mathrm{T}_{4}$ : Spacing of $60 \times 60 \mathrm{~cm}+50 \%$ RDF, $\mathrm{T}_{5}$ : Spacing of $60 \times 60 \mathrm{~cm}+75 \%$ RDF, $\mathrm{T}_{6}$ : Spacing of $60 \times 60 \mathrm{~cm}+100 \% \mathrm{RDF}, \mathrm{T}_{7}$ : Spacing of $60 \times 60 \mathrm{~cm}+0.75 \mathrm{~kg}$ FYM guni $^{-1}$ (Farmer's practice) and $\mathrm{T}_{8}$ : Spacing of $30 \mathrm{X}$ $10 \mathrm{~cm}+$ RDF: 50:40:25 kg NPK ha-1 (UAS package of practices). Small gunis or scoops were formed manually using spade at a intersect point of $60 \times 60 \mathrm{~cm}$ and $45 \times 45 \mathrm{~cm}$ spacing as the treatments from $T_{1}$ to $T_{7}$, well decomposed farmyard manure was applied @ 7.5 $\mathrm{t} \mathrm{ha}^{-1}$ for all the treatments except $\mathrm{T}_{7}$ (farmers practice) FYM required for each pit worked out and it was applied to the guni (spot application) and mixed with top soil. Whereas, for $\mathrm{T}_{7}$ (Farmers practice) FYM at the rate of $0.75 \mathrm{~kg}$ per guni was applied and mixed with top soil. For $\mathrm{T}_{8}$ (UAS package of practices) FYM was broadcasted and incorporated into the soil. $50 \mathrm{~kg} \mathrm{~N}, 40 \mathrm{~kg} \mathrm{P}_{2} \mathrm{O}_{5}$ and $25 \mathrm{~kg} \mathrm{~K}_{2} \mathrm{O} \mathrm{ha}{ }^{-1}$, recommended dose of fertilizers were applied. Fifty per cent of nitrogen and full dose of phosphorus and potassium were applied as basal dose for the gunis prepared. Whereas, remaining fifty per cent of nitrogen as per the treatments was 
applied at 30 DAT. Further, 20 days old two seedlings were transplanted in each guni. The growth parameters were recorded at periodical intervals of 30, 60 and 90 DAS from the randomly selected five plants in each treatment and growth indices were calculated by using following formulas.

\section{Relative Growth Rate (RGR) ( g g $^{-1}$ day $\left.^{-1}\right)$}

$\mathrm{RGR}=\frac{\log _{\mathrm{e}} \mathrm{W}_{2}-\log _{\mathrm{e}} \mathrm{W}_{1}}{\mathrm{t}_{2}-\mathrm{t}_{1}}$

Where, $\log _{\mathrm{e}}$ : Logarithm to the base, $\mathrm{W}_{1}$ : Dry weights of the plant at $t_{1}, W_{2}$ : Dry weights of the plant at $t_{2}$

\section{Crop Growth Rate (CGR) $\left(\mathrm{g}^{-1} \mathrm{~m}^{-2}\right.$ day $\left.^{-1}\right)$}

$\mathrm{CGR}=\frac{\left(\mathrm{W}_{2}-\mathrm{W}_{1}\right)}{\left(\mathrm{t}_{2}-\mathrm{t}_{1}\right) \times \text { spacing }}$

Where, $\mathrm{W}_{2}$ and $\mathrm{W}_{1}$ are the plant dry weight $(\mathrm{g})$ recorded at the time $t_{2}$ and $t_{1}$ (days), respectively.

Net Assimilation Rate (NAR) $\left(\mathrm{g} \mathrm{day}^{-1} \mathrm{dm}^{-2}\right)$

$\mathrm{NAR}=\frac{\left(\mathrm{W}_{2}-\mathrm{W}_{1}\right) \times\left(\log _{\mathrm{e}} \mathrm{L}_{2}-\log _{\mathrm{e}} \mathrm{L}_{1}\right)}{\left(\mathrm{t}_{2}-\mathrm{t}_{1}\right) \times\left(\mathrm{L}_{2}-\mathrm{L}_{1}\right)}$

Where, $\mathrm{W}_{2}$ and $\mathrm{W}_{1}$ are the dry weight of plant (g) recorded at time $t_{2}$ and $t_{1}$ (days) respectively. $\mathrm{L}_{2}$ and $\mathrm{L}_{1}$ are the leaf area $\left(\mathrm{dm}^{2}\right)$ recorded at the time $t_{2}$ and $t_{1}$ (days), respectively.

\section{Results and Discussion}

Effect of different spacing and fertilizers levels on growth and growth attributes

Different spacing and fertilizer levels significantly influenced the growth and growth attributes of finger millet. The results of the present investigation revealed that spacing of $60 \times 60 \mathrm{~cm}+100 \% \mathrm{RDF}$ significantly increased the plant height (31.20 $\mathrm{cm}, 78.29 \mathrm{~cm}, 90.80 \mathrm{~cm}$ at 30,60 and 90 DAT, respectively) which was significantly on par with spacing of $60 \times 60 \mathrm{~cm}+75 \%$ RDF $(29.27 \mathrm{~cm}, 75.47 \mathrm{~cm}, 86.68 \mathrm{~cm}$ at 30,60 and90 DAT, respectively) and spacing of $60 \mathrm{x}$ $60 \mathrm{~cm}+50 \%$ RDF $(29.53 \mathrm{~cm}, 76.73 \mathrm{~cm}$, $89.02 \mathrm{~cm}$ at 30,60 and 90 DAT, respectively). Significantly lower plant height was recorded with UAS package of practices $(29.53 \mathrm{~cm}$, $76.73 \mathrm{~cm}$ and $89.02 \mathrm{~cm}$ at 30, 60, and 90 DAT, respectively) (Table 1).

The same trend was also noticed in production of number of leaves per plant, spacing of $60 \mathrm{x}$ $60 \mathrm{~cm}+100 \%$ RDF recorded significantly higher number of leaves per plant (26.97, 45.40 and 54.34 at 30, 60 and 90 DAT, respectively), which was significantly on par with spacing of $60 \times 60 \mathrm{~cm}+75 \%$ RDF (26.57, 44.60, 52.80at 30, 60 and90 DAT, respectively). Increased plant height and number of leaves might be due to wider spacing with higher fertilizer levels resulted in less competition between plants for solar radiation, space and increased supply of nutrients and efficient utilization helps in better growth compared to UAS package of practices. These results corroborate the findings of Chittapur et al., (1994), Muthukrishnan and Subramanian (1980) and Hanumantha Rao et al., (1982).

There was a marked increase in the leaf area of finger millet in spacing of $60 \times 60 \mathrm{~cm}+100$ $\%$ RDF at 30 and 60 DAT (1137 and $7184 \mathrm{~cm}^{2}$ plant $^{-1}$ respectively) and is significantly on par with spacing of $60 \times 60$ $\mathrm{cm}+75 \%$ RDF at 30 and 60 DAT (1074 and $7053 \mathrm{~cm}^{2}$ plant ${ }^{-1}$, respectively) and spacing of $60 \mathrm{x} 60 \mathrm{~cm}+50 \%$ RDF (1016 and $6761 \mathrm{~cm}^{2}$ respectively). UAS package of practices recoded significantly lower leaf area of 273 and $632 \mathrm{~cm}^{2}$ plant ${ }^{-1}$, at 30 and 60 respectively. 
Table.1 Plant height $(\mathrm{cm})$ and Number of leaves plant ${ }^{-1}$ at different growth stages of finger millet as influenced by spacing and levels of NPK

\begin{tabular}{|c|c|c|c|c|c|c|}
\hline \multirow[t]{2}{*}{ Treatments } & \multicolumn{3}{|c|}{ Plant height (cm) } & \multicolumn{3}{|c|}{ Number of leaves (plant ${ }^{-1}$ ) } \\
\hline & 30 DAT & 60 DAT & 90 DAT & 30 DAT & 60 DAT & 90 DAT \\
\hline $\mathrm{T}_{1}$ : Spacing of $45 \times 45 \mathrm{~cm}+50 \%$ RDF & 27.00 & 60.20 & 79.79 & 19.97 & 33.80 & 45.13 \\
\hline $\mathrm{T}_{2}$ : Spacing of $45 \times 45 \mathrm{~cm}+75 \%$ RDF & 27.53 & 63.43 & 83.05 & 21.00 & 36.80 & 46.53 \\
\hline $\mathrm{T}_{3}$ : Spacing of $45 \times 45 \mathrm{~cm}+100 \%$ RDF & 28.07 & 65.87 & 87.40 & 23.57 & 39.60 & 47.70 \\
\hline $\mathrm{T}_{4}$ : Spacing of $60 \mathrm{X} 60 \mathrm{~cm}+50 \% \mathrm{RDF}$ & 29.27 & 75.47 & 86.68 & 24.53 & 43.47 & 51.73 \\
\hline $\mathrm{T}_{5}:$ Spacing of $60 \times 60 \mathrm{~cm}+75 \% \mathrm{RDF}$ & 29.53 & 76.73 & 89.02 & 26.57 & 44.60 & 52.80 \\
\hline$T_{6}:$ Spacing of $60 \times 60 \mathrm{~cm}+100 \%$ RDF & 31.20 & 78.29 & 90.80 & 26.97 & 45.40 & 54.33 \\
\hline$T_{7}:$ Spacing of 60 X $60 \mathrm{~cm}+0.75 \mathrm{~kg} \mathrm{FYM} \mathrm{guni}^{-1}$ (Farmer's practice) & 24.40 & 58.33 & 86.10 & 18.13 & 30.13 & 43.87 \\
\hline $\begin{array}{l}\mathrm{T}_{8}: \text { Spacing of } 30 \times 10 \mathrm{~cm}+\mathrm{RDF}: 50: 40: 25 \mathrm{~kg} \mathrm{NPK} \mathrm{ha}^{-1} \text { (UAS package of } \\
\text { practice) }\end{array}$ & 20.80 & 52.25 & 71.12 & 17.37 & 21.00 & 38.67 \\
\hline S.Em \pm & 0.80 & 2.70 & 1.65 & 0.95 & 1.23 & 0.82 \\
\hline C.D $(P=0.05)$ & 2.42 & 8.18 & 5.00 & 2.89 & 3.73 & 2.50 \\
\hline
\end{tabular}

Table.2 Leaf area $\left(\mathrm{cm}^{2}\right.$ plant $\left.^{-1}\right)$ and number of tillers (plant $\left.{ }^{-1}\right)$ at different growth stages of finger millet as influenced by spacing and levels of NPK

\begin{tabular}{|c|c|c|c|c|c|c|}
\hline \multirow[t]{2}{*}{ Treatments } & \multicolumn{3}{|c|}{ Leaf area $\left(\mathrm{cm}^{2}\right.$ plant $\left.{ }^{-1}\right)$} & \multicolumn{3}{|c|}{ Number of tillers (plant ${ }^{-1}$ ) } \\
\hline & 30 DAT & 60 DAT & 90 DAT & 30 DAT & $60 \mathrm{DAT}$ & 90 DAT \\
\hline $\mathrm{T}_{1}$ : Spacing of $45 \times 45 \mathrm{~cm}+50 \% \mathrm{RDF}$ & 793 & 5604 & 17490 & 2.87 & 8.47 & 12.93 \\
\hline $\mathrm{T}_{2}:$ Spacing of $45 \times 45 \mathrm{~cm}+75 \%$ RDF & 879 & 6146 & 18175 & 3.03 & 9.17 & 13.20 \\
\hline $\mathrm{T}_{3}:$ Spacing of $45 \times 45 \mathrm{~cm}+100 \%$ RDF & 912 & 6558 & 19202 & 3.17 & 9.60 & 13.80 \\
\hline $\mathrm{T}_{4}:$ Spacing of $60 \times 60 \mathrm{~cm}+50 \%$ RDF & 1016 & 6761 & 19990 & 3.33 & 9.73 & 14.27 \\
\hline $\mathrm{T}_{5}:$ Spacing of $60 \mathrm{X} 60 \mathrm{~cm}+75 \% \mathrm{RDF}$ & 1074 & 7053 & 21140 & 3.50 & 10.02 & 14.40 \\
\hline $\mathrm{T}_{6}:$ Spacing of $60 \times 60 \mathrm{~cm}+100 \%$ RDF & 1137 & 7184 & 26322 & 3.73 & 10.20 & 17.60 \\
\hline$T_{7}:$ Spacing of 60 X $60 \mathrm{~cm}+0.75 \mathrm{~kg}$ FYM guni ${ }^{-1}$ (Farmer's practice) & 834 & 6368 & 15340 & 2.93 & 9.67 & 11.27 \\
\hline $\begin{array}{l}\text { T: Spacing of } 30 \times 10 \mathrm{~cm}+\text { RDF: } 50: 40: 25 \mathrm{~kg} \mathrm{NPK} \mathrm{ha}^{-1} \text { (UASpackage } \\
\text { of practice) }\end{array}$ & 273 & 632 & 1200 & 2.17 & 2.70 & 4.67 \\
\hline S.Em \pm & 41 & 263 & 844 & 0.14 & 0.37 & 0.60 \\
\hline C.D $(P=0.05)$ & 125 & 798 & 2560 & 0.43 & 1.11 & 1.81 \\
\hline
\end{tabular}


Table.3 Effect of spacing and levels of NPK on dry matter accumulation ( $\left.\mathrm{g} \mathrm{plant}^{-1}\right)$ at growth stages of finger millet

\begin{tabular}{|c|c|c|c|c|c|c|c|c|c|}
\hline \multirow[t]{2}{*}{ Treatments } & \multicolumn{3}{|c|}{30 DAT } & \multicolumn{3}{|c|}{$60 \mathrm{DAT}$} & \multicolumn{3}{|c|}{90 DAT } \\
\hline & Leaf & Stem & Total & Leaf & Stem & Total & Leaf & Stem & Total \\
\hline $\mathrm{T}_{1}:$ Spacing of $45 \times 45 \mathrm{~cm}+50 \%$ RDF & 0.78 & 0.77 & 1.55 & 2.46 & 4.14 & 6.6 & 6.95 & 12.07 & 19.02 \\
\hline $\mathrm{T}_{2}:$ Spacing of $45 \times 45 \mathrm{~cm}+75 \%$ RDF & 0.83 & 0.91 & 1.73 & 2.53 & 4.22 & 6.75 & 7.12 & 12.29 & 19.41 \\
\hline$T_{3}$ : Spacing of $45 \times 45 \mathrm{~cm}+100 \%$ RDF & 0.86 & 0.92 & 1.78 & 3.10 & 4.46 & 7.56 & 7.30 & 12.48 & 19.78 \\
\hline$T_{4}:$ Spacing of $60 \times 60 \mathrm{~cm}+50 \%$ RDF & 0.87 & 0.94 & 1.81 & 3.46 & 4.70 & 8.16 & 7.50 & 12.69 & 20.19 \\
\hline$T_{5}:$ Spacing of $60 \mathrm{X} 60 \mathrm{~cm}+75 \%$ RDF & 0.93 & 0.96 & 1.89 & 3.97 & 5.24 & 9.21 & 7.56 & 12.71 & 20.27 \\
\hline$T_{6}$ : Spacing of $60 \times 60 \mathrm{~cm}+100 \%$ RDF & 0.97 & 1.08 & 2.06 & 4.83 & 5.75 & 10.58 & 7.76 & 12.86 & 20.62 \\
\hline $\begin{array}{l}T_{7}: \text { Spacing of } 60 \mathrm{X} 60 \mathrm{~cm}+0.75 \mathrm{~kg} \text { FYM guni } \\
\text { (Farmer's practice) }\end{array}$ & 0.81 & 0.90 & 1.71 & 3.73 & 4.94 & 8.67 & 7.07 & 11.50 & 18.57 \\
\hline $\begin{array}{l}\mathrm{T}_{8}: \text { Spacing of } 30 \mathrm{X} 10 \mathrm{~cm}+\mathrm{RDF}: 50: 40: 25 \mathrm{~kg} \\
\mathrm{NPK}^{-1} \text { (UAS package of practice) }\end{array}$ & 0.55 & 0.55 & 1.11 & 2.29 & 3.30 & 5.59 & 6.24 & 10.58 & 16.82 \\
\hline S.Em \pm & 0.02 & 0.04 & 0.04 & 0.23 & 0.22 & 0.16 & 0.10 & 0.23 & 0.47 \\
\hline C.D $(p=0.05)$ & 0.06 & 0.11 & 0.11 & 0.73 & 0.68 & 0.48 & 0.31 & 0.68 & 1.42 \\
\hline C.V & 6.82 & 7.14 & 6.90 & 12.2 & 8.42 & 10.2 & 6.30 & 7.18 & 8.96 \\
\hline
\end{tabular}

Table.4 Relative growth rate $\left(\mathrm{g} \mathrm{day}^{-1} \mathrm{dm}^{-2}\right)$, crop growth rate $\left(\mathrm{g} \mathrm{dm}^{-2}\right.$ day $\left.{ }^{-1}\right)$, net assimilation rate $\left(\mathrm{g} \mathrm{day}^{-1} \mathrm{dm}^{-2}\right)$ and seed yield $\left(\mathrm{kg} \mathrm{ha}^{-1}\right)$ in finger millet as influenced by different spacing and levels NPK application

\begin{tabular}{|c|c|c|c|c|c|c|c|}
\hline \multirow[t]{2}{*}{ Treatments } & \multicolumn{2}{|c|}{ RGR } & \multicolumn{2}{|c|}{ CGR } & \multicolumn{2}{|c|}{ NAR } & \multirow{2}{*}{$\begin{array}{l}\text { Seed yield } \\
\left(\mathrm{kg} \mathrm{ha}^{-1}\right)\end{array}$} \\
\hline & $\begin{array}{l}30-60 \\
\text { DAS }\end{array}$ & $\begin{array}{l}60-90 \\
\text { DAS }\end{array}$ & $\begin{array}{l}30-60 \\
\text { DAS }\end{array}$ & $\begin{array}{l}60-90 \\
\text { DAS }\end{array}$ & 30-60 DAS & $60-90 \mathrm{DAS}$ & \\
\hline $\mathrm{T}_{1}$ : Spacing of $45 \times 45 \mathrm{~cm}+50 \%$ RDF & 0.335 & 0.168 & 5.732 & 3.936 & 0.0396 & 0.0262 & 3172 \\
\hline $\mathrm{T}_{2}:$ Spacing of $45 \times 45 \mathrm{~cm}+75 \% \mathrm{RDF}$ & 0.369 & 0.167 & 5.938 & 4.216 & 0.0431 & 0.0301 & 3200 \\
\hline $\mathrm{T}_{3}$ : Spacing of $45 \times 45 \mathrm{~cm}+100 \% \mathrm{RDF}$ & 0.374 & 0.193 & 6.010 & 4.591 & 0.0476 & 0.0387 & 3355 \\
\hline $\mathrm{T}_{4}:$ Spacing of $60 \mathrm{X} 60 \mathrm{~cm}+50 \% \mathrm{RDF}$ & 0.407 & 0.212 & 6.437 & 5.188 & 0.0596 & 0.0463 & 3848 \\
\hline$T_{5}:$ Spacing of $60 \mathrm{X} 60 \mathrm{~cm}+75 \%$ RDF & 0.414 & 0.244 & 7.099 & 5.495 & 0.0637 & 0.0539 & 4092 \\
\hline $\mathrm{T}_{6}:$ Spacing of $60 \mathrm{X} 60 \mathrm{~cm}+100 \% \mathrm{RDF}$ & 0.422 & 0.284 & 7.230 & 5.841 & 0.0721 & 0.0643 & 4166 \\
\hline$T_{7}$ : Spacing of 60 X $60 \mathrm{~cm}+0.75 \mathrm{~kg} \mathrm{FYM} \mathrm{guni}^{-1}$ (Farmers practice) & 0.401 & 0.232 & 6.116 & 4.791 & 0.0590 & 0.419 & 3606 \\
\hline $\begin{array}{l}\mathrm{T}_{8} \text { : Spacing of } 30 \text { X } 10 \mathrm{~cm}+\mathrm{RDF}: 50: 40: 25 \mathrm{~kg} \mathrm{NPK} \mathrm{ha}^{-1} \text { (UAS } \\
\text { package of practice) }\end{array}$ & 0.330 & 0.149 & 4.928 & 3.038 & 0.0298 & 0.0163 & 1948 \\
\hline C.D $(p=0.05)$ & 0.0013 & 0.0036 & 0.010 & 0.030 & 0.0009 & 0.0002 & 69.91 \\
\hline
\end{tabular}


At 90 DAT, spacing of $60 \times 60 \mathrm{~cm}+100 \%$ RDF resulted in significantly more leaf area (26322 $\mathrm{cm}^{2}$ plant $^{-1}$ ) compared to all other treatments. Wider spacing produced robust and healthy plants produced more number of leaves due to less competition between plants for light, water and increased fertilizer level automatically increased the nutrient availability finally helped to get more leaf area. The results are in confirmative with the findings of Krishnamurthy (1988).

Planting at $60 \times 60 \mathrm{~cm}$ with $100 \% \mathrm{RDF}$ recorded significantly higher number of tillers (19.86 tillers hill ${ }^{-1}$ ) followed by a spacing of $60 \times 60 \mathrm{~cm}+75 \% \operatorname{RDF}$ (18.60 tillers hill ${ }^{-1}$ ). Whereas, UAS package of practices resulted in significantly lower number of tiller hill ${ }^{-1}$ at all stages and at harvest (4.67 tillers hill ${ }^{-1}$ ) (Table 2). The higher number of tillers at wider spacing intercepted more of solar radiation, water and increased nutrient availability helped to produce significantly higher number of tillers. Again less competition between plants due to wider space allowed the individual plants to develop massive root system. Better aeration at wider spacing resulted in healthy plant growth with more tillers. These results are in conformity with the findings of Narasimhamurthy and Hedge, (1981).

The dry matter production is the result of cumulative and complementary effect of plant height, number of leaves, leaf area, root weight. Dry matter production differed significantly due to different spacings and NPK levels. Among the different treatments significantly higher dry matter accumulation was rerecorded at a spacing of $60 \times 60 \mathrm{~cm}+$ $100 \%$ RDF as compared to all other treatments. The higher total dry matter production was attributed to better plant growth which resulted in higher dry matter accumulation in leaves and stem at early growth stages and better translocation to ear heads during later stages. Higher dry matter production in leaf $\left(7.85 \mathrm{~g} \mathrm{plant}^{-1}\right)$, stem (14.55 $\left.\mathrm{g} \mathrm{plant}^{-1}\right)$, ear head $\left(20.30 \mathrm{~g} \mathrm{plant}^{-1}\right)$ and total dry matter $\left(42.70 \mathrm{~g} \mathrm{plant}^{-1}\right)$ was noticed due to spacing of $60 \times 60 \mathrm{~cm}+100 \%$ RDF. These results are in conformity with the findings of Kalaraju et al., (2009) and Mishra et al., (1973) (Table 3).

Different spacing and levels of fertilizers influenced the growth indices significantly. At 30-60 days and 60-90 days intervals, significantly higher growth indices like Relative Growth Rate $\left(0.422 \mathrm{~g} \mathrm{day}^{-1} \mathrm{dm}^{2}\right.$ and $0.284 \mathrm{~g} \mathrm{day}^{-1} \mathrm{dm}^{2}$ at 30-60 days and 60-90 days interval, respectively), Crop Growth Rate $\left(7.230 \mathrm{~g} \mathrm{dm}^{-2} \mathrm{day}^{-1}\right.$ and $5.841 \mathrm{~g} \mathrm{dm}^{-2}$ day $^{-1}$ at 30-60 days and 60-90 days interval, respectively) and Net Assimilation Rate $\left(0.0637 \mathrm{~g} \mathrm{day}^{-1} \mathrm{dm}^{2}\right.$ and $0.0539 \mathrm{~g} \mathrm{day}^{-1} \mathrm{dm}^{2}$ at 30-60 days and 60-90 days interval, respectively) were recorded with spacing of $60 \times 60 \mathrm{~cm}+100 \%$ RDF application.

Increase in growth indices might be due to availability of wider spacing and adequate nutrients increased the leaf area and total dry matter production and resulted in higher growth indices. Higher growth parameters like higher plant, higher number of leaves plant $^{-1}$, number of tillers hill ${ }^{-1}$ and dry matter accumulation in leaf, stem and total plant ${ }^{-}$ ${ }^{1}$ helps in better photosynthesis and mobilization of photosynthates from source to sink thus, resulted in production of higher seed yield $\left(4166 \mathrm{~kg} \mathrm{ha}^{-1}\right)$ with spacing of $60 \mathrm{x}$ $60 \mathrm{~cm}+100 \%$ RDF application (Table 4).

A result obtained from present investigation indicates that application of varied levels of NPK fertilizers with different spacing significantly influences the growth and growth attributes of finger millet. Wider spacing and adequate supply of plant nutrient helps in better photosynthesis and growth of finger millet which helps in higher seed yield. 


\section{References}

Anonymous, 2013, Annual Report, All India Coordinated Research Project for Dryland Agriculture, University of Agricultural Science, Bengaluru, Karnataka, India. pp: 31-36.

Basavaraj, T. B. and Rao, M. R. G., 1997, Integrated nutrient management in finger millet under rainfed conditions. Karnataka J. Agril. Sci., 10(3): 855-856

Chittapur, B. M., Kulkarni, B. S., Hiremath, S. N. and Hosamani, M. M., 1994, Influence of nitrogen and phosphorus on the growth ad yield of finger millet. Indian J. Agron., 39(4): 657 - 659.

Gomez, K. A. and Gomez, A., 1984, Statistical procedures for agricultural research. 2nd edition, John Willey and Sons, Inc. New York, USA. pp: 234237

Hanumantharao, Y., Bapireddy, Y., Yellamanda Reddy, T. and Shankara Reddy, G. H., 1982, Effect of different levels of nitrogen, phosphorus and potassium on the growth and yield of finger millet. Andhra Agril. J., 29(1): 37-41.

Kalaraju, K., Kumar, N. S., Nagaraja, N. and Ningappa, K. B., 2009, Effect of methods of planting on growth and yield of finger millet genotypes under organic farming. Res. Crops, 10: 20-24.

Krishnamurthy, T. D., 1988, Effect of levels of nitrogen and spacing on the growth and yield of ragi (Eleusine coracana $\mathrm{L}$. Gaertn.) genotypes. M.Sc. (Agri.) Thesis, Univ. Agril. Sci., Bengaluru.

Mallikarjun Hosapalya, 2005, NettiRagi-An introduction to farmer's method of ragi cultivation, Dhanya Pub. Sadashivanagar, Tumkur, Karnataka, pp: 1-39

Mishra, A., Patra, S. S. and Patnaik, R. N., 1973, Response of ragi to spacing and nitrogen, Indian J. Agron., 18: 264-268.

Muthukrishnan, P. and Subramanian, S., 1980, Weed control in maize under graded nitrogen levels. Madras Agril. J., 67: 785-789.

Narasimhamurthy and Hegde, B. R., 1981, Tillering in relation to intra-row competition in ragi under rainfed conditions. Indian J. Agron., 26(3): 337-338.

Ramamurthy, K., Christoper, Louduraj, A., Alagudurai, S. and Kandaswamy, O. S., 2004, Effect of crop residue management of early season legumes on the succeeding rainfed finger millet. MdrasAgril. J., 91(4-6): 180-183.

\section{How to cite this article:}

Prakasha, G., K.N. Kalyana Murthy, A.S. Prathima and Rohani N. Meti. 2018. Effect of Spacing and Nutrient Levels on Growth Attributes and Yield of Finger Millet (Eleusine coracana L. Gaertn) Cultivated under Guni Planting Method in Red Sandy Loamy Soil of Karnataka, India. Int.J.Curr.Microbiol.App.Sci. 7(05): 1337-1343. doi: https://doi.org/10.20546/ijcmas.2018.705.160 